\title{
The alien freshwater fish of Mount Galunggung, West Java, Indonesia
}

\author{
HARYONO^, GEMA WAHYUDEWANTORO \\ Zoology Division, Research Center for Biology, Indonesian Institute of Sciences. Jl. Raya Jakarta-Bogor Km.46, Cibinong, Bogor 16911, West Java, \\ Indonesia. Tel.+62-21-8765056, Fax.: +62-21-8765068. `email: ikharyono@yahoo.com
}

Manuscript received: 23 December 2019. Revision accepted: 11 March 2020.

\begin{abstract}
Haryono, Wahyudewantoro G. 2020. The alien freshwater fish of Mount Galunggung, West Java, Indonesia. Biodiversitas 21: 1407-1414. Mt. Galunggung, located in West Java, Indonesia, is an active volcano renowned for its deadly eruption in 1982 . This area has many waters bodies, but the fish communities have not been recorded, especially the alien or introduced fish species. Hence, the objective of the present study was to determine the alien fish diversity, abundance, local distribution and utilization in Galunggung vicinity. The study was done in March 2013 using survey method covering 10 stations. Fish sampling was based on catch per unit of effort (CPUE) using mainly electrofishing, gillnet and cast net. A total of 24 species were recorded during the survey, in which 13 were listed as introduced species. Poecilia reticulata was the dominant species with 7.4 ind./St and followed by Xiphophorus helleri with 5.3 ind./St. Both species were also widely distributed on the sites with $70 \%$ local distribution. The alien species in this area are mostly used for ornamental fish.
\end{abstract}

Keywords: Abundance, alien species, distribution, utilization

\section{INTRODUCTION}

Galunggung is a well-known volcano in West Java for its nine month-big explosions in 1982, where the volcanic materials spread out as far as Australia. The mountain is located in southwest Tasikmalaya District, West Java Province, Indonesia. Until now, Galunggung Mountain has become an interesting tourist destination. Fadjarajani et al. (2019) reported number of both local and foreign tourists to reach hundreds and thousands of people per year. One of the points of interest in this area is Mt. Galunggung crater which positioned at $2,168 \mathrm{~m}$ above sea level, which now already changed into a lake. The water of this lake flows to tributaries or streams then ends in Citanduy River (Prasetyo 2004). The water which forms the lake comes from rainwater and meteoric water, which is abundant around the peak of Mt. Galunggung supported with the waterproof character of the bottom of the crater (De Hoog et al. 2001)

Galunggung areas are potential habitats for freshwater fish because of the presence of many streams or tributaries. However, until now, the presence of alien or introduced species there has not yet documented. Minchin et al. (2013) defined alien species as species which were moved out of their area to relatively new region for recreation, trade, food and other economic interests across world. Local people of Galunggung cultured many alien fish species in ponds for ornamental. The alien fish species also were spread to many freshwater areas in Indonesia. Some species probably have invasive characters and threats to native species. The invasive alien species (IAS) may cause myriad negative impacts, such as ecosystem disruption, health issues to human, animal, and plant, economic damage and species extinctions (Dickey et al.2018; Jakubcinova et al. 2018). Moreover, the negative impacts of introduced fish species are hybridization with congeneric species, parasite transfers between cultured and wild individuals, extirpations of native fish due to competition and predation, and also cascading food web impacts at community and ecosystem levels (Woodford et al. 2016).

Introduced fish species are important factors affecting the changes of abundance of aquatic communities and decrease in fish diversity ( $\mathrm{Li}$ et al. 2014; Yao et al. 2014). The fish diversity of West Java, which including Mt. Galunggung area is high, approximately 185 species (Herawati et al. 2019). The utilization of native fish in this area is not yet optimal, but the introduced species are already widely distributed. Hence, this study focuses on the introduced or alien freshwater fish species in Mt. Galunggung areas. The aim of this study was to determine the total fish diversity (native and alien), alien fish diversity, abundance, distribution, and utilization of fish. The main purpose of this study is to increase our understanding of the alien freshwater fish in Indonesia. The results of this study are expected to help in management policy of fish resources, especially for native fish species.

\section{MATERIALS AND METHODS}

\section{Study site}

This study was conducted in Mt. Galunggung areas, including Tasikmalaya District, West Java Province, Indonesia. Fish sampling covered 10 stations with ranges altitude between 585 and $1130 \mathrm{~m}$ above sea level (Table 1). The most extreme station was Mt. Galunggung crater, because of its nature as a small lake (Figure 1). 


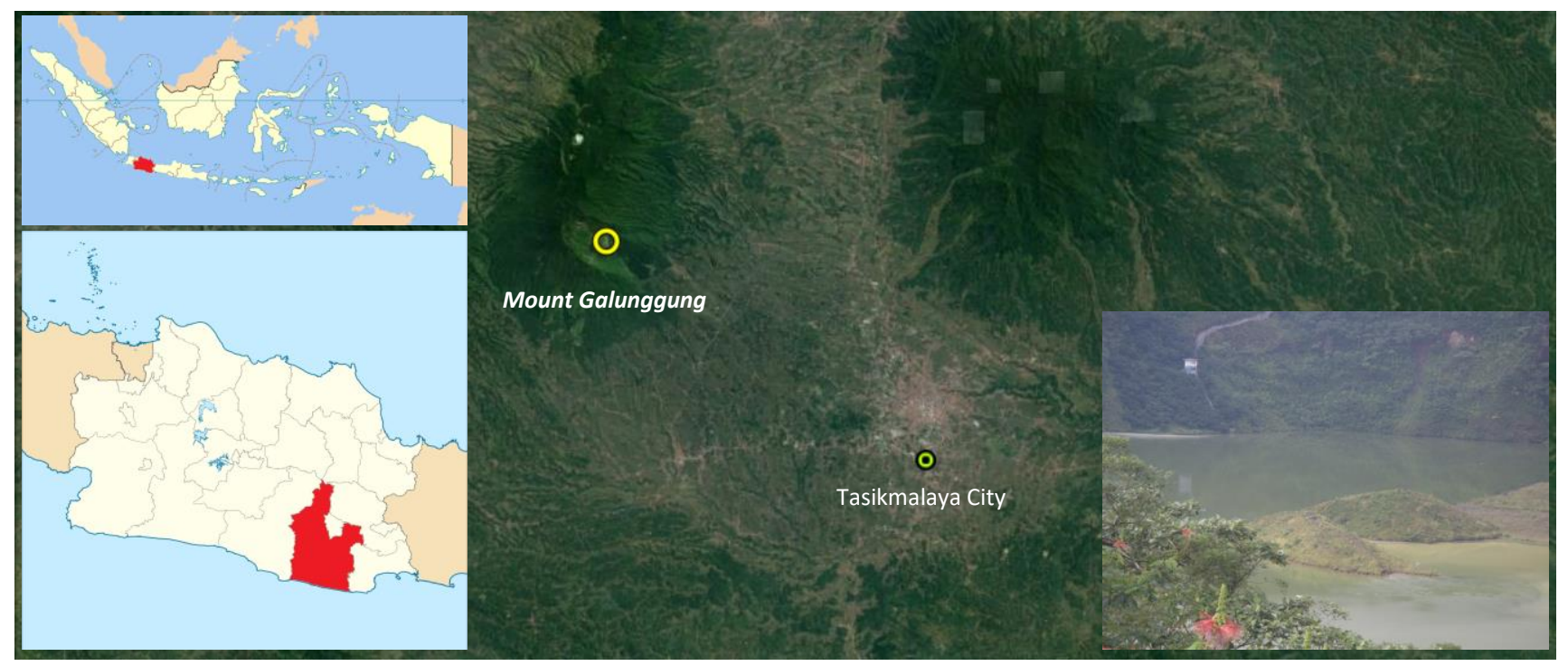

Figure 1. The position of Mt. Galunggung and its crater (yellow circle), in Tasikmalaya District, West Java, Indonesia

Table 1. Study sites in Mt. Galunggung, Tasikmalaya District, West Java, Indonesia

\begin{tabular}{|c|c|c|c|}
\hline Stations & Station name & Coodinats & Altitude (m) \\
\hline $\begin{array}{ll}\text { St.1 } \\
\end{array}$ & Cibukur stream ( lower parts 1 ) & $07^{\circ} 16^{\prime} 09.0^{\prime \prime}$ S $108^{\circ} 06^{\prime} 08.0^{\prime \prime} \mathrm{E}$ & 661 \\
\hline St. 2 & Cibukur stream (upper parts) & $07^{\circ} 15^{\prime} 59.0^{\prime \prime} \mathrm{S} 108^{\circ} 05^{\prime} 58.8^{\prime \prime} \mathrm{E}$ & 715 \\
\hline St.3 & Cipongkor stream & $07^{\circ} 16^{\prime} 10.8^{\prime \prime} \mathrm{S} 108^{\circ} 06^{\prime} 07.8^{\prime \prime} \mathrm{E}$ & 668 \\
\hline St.4 & Drainage system & $07^{\circ} 16^{\prime} 05.2^{\prime \prime} \mathrm{S} 108^{\circ} 05^{\prime} 55.0^{\prime \prime} \mathrm{E}$ & 710 \\
\hline St.5 & Cikunir stream & $07^{\circ} 16^{\prime} 19.4^{\prime \prime} \mathrm{S} 108^{\circ} 05^{\prime} 50.8^{\prime \prime} \mathrm{E}$ & 687 \\
\hline St.6 & Galunggung cauldron as lake & $07^{\circ} 15^{\prime} 30.4^{\prime \prime} \mathrm{S} 108^{\circ} 04^{\prime} 32.3^{\prime \prime} \mathrm{E}$ & 1130 \\
\hline St.7 & Ciasem stream & $07^{\circ} 16^{\prime} 45.6^{\prime \prime} \mathrm{S} 108^{\circ} 07^{\prime} 03.0^{\prime \prime} \mathrm{E}$ & 585 \\
\hline St. 8 & Cibukur stream (lower parts 2) & $07^{\circ} 16^{\prime} 51.1^{\prime \prime} \mathrm{S} 108^{\circ} 06^{\prime} 59.0^{\prime \prime} \mathrm{E}$ & 596 \\
\hline St.9 & Banjaran stream & $07^{\circ} 15^{\prime} 49.3^{\prime \prime}$ S $108^{\circ} 06^{\prime} 27.4^{\prime \prime} \mathrm{E}$ & 684 \\
\hline St.10 & Citunggul stream & $07^{\circ} 16^{\prime} 53.4^{\prime \prime} \mathrm{S} 108^{\circ} 06^{\prime} 50.6^{\prime \prime} \mathrm{E}$ & 591 \\
\hline
\end{tabular}

\section{Fish sampling and identification}

Fish samplings were conducted based on catch per unit of effort methods (CPUE) in March 2013 in the 10 stations. The deployed fishing gears were mainly fish electro shockers which were powered by battery motorcycle with capacity 12 volt and 10 amperes; completed with gill net with 1 inch mesh size and cast net with $3 \mathrm{~m}$ diameter. Fish sampling was conducted for 2 hours for each station. The collected fish were counted, sub-samples representing each species were cleaned and photographed, and later preserved in $10 \%$ formalin in plastic bags. The bags were tagged with sampling location, date, and the local name of the fish. These fish samples were transported to the laboratory with formalin replaced to ethanol $70 \%$. Fish specimens were identified based on Weber and de Beaufort (1913), Mohsin and Ambak (1983), Inger and Chin (1962), Roberts (1989; 1993), Kottelat et al. (1993), Axelrods et al. (1995), and Eschmeyer (1998). Validation of the scientific name of fish species referred to Kottelat (2013); Froese and Pauly (2019).

Following identification and documentation, the status of each fish (alien and native) was determined based on the Global Invasive Species Database (http://www.issg.org/ database/welcome/). Additional information on the present status of the fishes was also obtained from Fishbase data (Froese and Pauly 2019).

\section{Data analysis}

Analysis of covered abundance and local distribution. The abundance of fish species according to Misra (1968) calculated as follows:

\section{Abundance $=\mathbf{N}_{\mathbf{i}} / \mathbf{N} . \mathbf{S t}_{\mathrm{i}}$}

Where, $\mathrm{Ni}=$ number individual of species-i; N.St.i $=$ number of the stations where species-i was found

The local distribution or frequency of incidence (FOI) of each species was estimated according to Muchlisin and Azizah (2009) and Muchlisin et al. (2015) as follows:

\section{$\mathrm{FOI}=(\mathrm{Ni} \cdot \mathrm{St} / \mathrm{Ni} \cdot \mathrm{St}) \times \mathbf{1 0 0}$}

Where, Ni.St $=$ total number of stations where the species $\mathrm{i}$ where found, N.St $=$ total number of sampling stations. 


\section{RESULTS AND DISCUSSION}

\section{Fish diversity}

A total of 875 individual fish were collected, which comprised of 24 species and 9 families in Mt. Galunggung areas (Table 2). Number of fish species in these areas was lower compared with that of Gunung Machinchang, Pulau Langkawi Malaysia, which recorded of 27 species (Azmir et al. 2010). Cichlidae predominated the area with 10 species, followed by Cyprinidae with 4 species and other families consist of 1 to 2 species. The number of fish species from Mt. Galunggung was higher compared to nearby areas, such as Gunung Sawal with 12 reported species (Haryono 2017) and Gunung Telaga Bodas with 17 species (Haryono 2018). Species composition in Mt. Galunggung was different compared to other areas. Cyprinidae has been the dominant family in general, such as in Klawing river at Central Java (Suryaningsih et al. 2018), Batangtoru River, South Tapanuli, North Sumatra (Roesma et al. 2016), Gangga river, India (Pathak et al. 2013), and Danau Biwa, Japan (Kawanabe 1996 in Leveque et al. 2008). Previously, Kottelat et al. (1993) stated that Cyprinidae is a very large family of freshwater fishes found throughout the world, with the exception of Madagascar, Australia, New Zealand, and South America. Froese and Pauly (2019) reported 3163 species and 376 genera from the family of Cyprinidae. The total introduced species in Mt. Galunggung was higher than native species, which were 13 and 11 species, respectively (Figure 2). Generally, the fish diversity in mountain areas is low because of its extreme habitat and mostly are native species. Mt. Galunggung has both native and nonnative/alien fish species, and against the commonality, the number of non-native species is higher than native species. Number of the native fish species in this mountain was almost similar to that of Gunung Sawal (Haryono 2017). Occurrence of many alien fish species in Mt. Galunggung could be caused by 1) Local people cultured the alien species in fishpond and accidentally released them to streams (Kiruba-Sankar et al. 2018); 2) Local people released the alien species directly to the streams. Unexpectedly, the streams have appropriate niche for supporting the life of alien species. The availability of niche for alien fish species probably due to the impact from explosion of Mt. Galunggung. Mostly, the alien fish species in these areas are potential for ornamental. This information would be important for stakeholders related to management of fish resources, especially about conservation of the native species.

Based on abundance and local distribution, Barbodes binotatus was the predominant species (53.3 ind./St), followed by Osteochilus vittatus (15.9 ind/St.) and Poecilia reticulata (7.4 ind./St.). The local distribution was dominated by Barbodes binotatus (100\%) and followed by Osteochilus vittatus (80\%) (Table 1). Barbodes binotatus is a cosmopolitan species in Sundaland, covering Sumatra, Java, and Kalimantan with habitat including stream, tributary, lake, and swamp. This species also prefers shallow water habitat with vegetation.

Barbodes binotatus and Ostechilus vittatus were not only abundant in Mt. Galunggung but also Gunung Ciremai National Park and Gunung Halimun National Park. Their habitats are shallow stream, slow current water, and converted environments such as rice field or plantation (Beamish et al. 2006; Suryaningsih et al. 2018). This condition causes these species to pose herbivore feeding behavior with Bacillariophyceae, Chlorophyceae, Cyanophyceae and detritus as the additional diet (Aryani et al. 2017; Batubara et al. 2019). Guppy (Poecilia reticulata) is a species with small body size, high adaptation, and fast reproduction rate which make its population abundant (Meffe and Snelson 1989; Montag et al. 2011).

The species composition in Galunggung was interesting because we did not find common species of mountain fishes such as Rasbora lateristriata and Glyptothorax major, as reported from Gunung Slamet (Haryono 2012) and Gunung Sawal (Haryono 2017). The phenomenon might be influenced by big eruption of Mt. Galunggung in 1982. The fish diversity among stations of Galunggung areas was between 4 and 13 species, and highest was in St.7 (Ciasem) and lower part Cibukur (St.9), each with 13 species. Commonly, the fish diversity in mountain areas is low because of its extreme conditions, such as high water current, low temperature, and rocky bottom.

\section{Alien fish species}

The alien fish species found in Mt. Galunggung areas consist of 13 species from 3 families (Table 2). The range of species number among stations was from 1 to 8 species, and the highest was in St.7 (Ciasem). The dominant family of alien species was Cichlidae with 10 species. This family is highly adaptive and fast in reproduction, therefore, it is abundant in many freshwaters. Cichlids have successfully invaded new ecosystems in many different parts of the world (Liem 1973, Harrison 2014). Cichlidae has high number of species with 1713 and 250 genera (Froese and Pauly 2019). The geography distributions of this family are Africa, Central America and South America (Kottelat et al. 1993).



Figure 2. Number of native and non-native/alien fish species in Mt. Galunggung, Tasikmalaya District, West Java, Indonesia 
Table 2. Species composition of Mt. Galunggung areas in Tasikmalaya District, West Java, Indonesia

\begin{tabular}{|c|c|c|c|c|c|c|c|c|c|c|c|c|c|c|c|}
\hline \multirow[b]{2}{*}{ Species } & \multicolumn{10}{|c|}{ Stations } & \multirow[b]{2}{*}{$\begin{array}{l}\text { Total } \\
\text { (ind.) }\end{array}$} & \multirow[b]{2}{*}{$\begin{array}{l}\text { Abund } \\
\text { (ind./St.) }\end{array}$} & \multirow{2}{*}{$\begin{array}{l}\text { Loc } \\
\text { Dist } \\
(\%) \\
\end{array}$} & \multirow[b]{2}{*}{ Status } & \multirow[b]{2}{*}{ Potential } \\
\hline & 1 & 2 & 3 & 4 & 5 & 6 & 7 & 8 & 9 & 10 & & & & & \\
\hline \multicolumn{16}{|l|}{ Family Anguilllidae } \\
\hline Anguilla bicolor & - & - & - & - & + & - & - & - & - & - & 1 & 1 & 10 & $\mathrm{~N}$ & $\mathrm{C}$ \\
\hline \multicolumn{16}{|l|}{ Family Cyprinidae } \\
\hline Barbodes binotatus & + & + & + & + & + & + & + & + & + & + & 533 & 53.3 & 100 & $\mathrm{~N}$ & $\mathrm{C}$ \\
\hline Labiobarbus leptocheilus & - & + & - & - & - & - & - & - & - & - & 2 & 2 & 10 & $\mathrm{~N}$ & $\mathrm{C}$ \\
\hline Osteochilus vittatus & + & + & + & + & + & - & + & + & - & + & 127 & 15.9 & 80 & $\mathrm{~N}$ & $\mathrm{C}$ \\
\hline Systomus orphoides & - & - & + & - & - & - & - & - & - & - & 1 & 1 & 10 & $\mathrm{~N}$ & $\mathrm{C}$ \\
\hline \multicolumn{16}{|l|}{ Family Clariidae } \\
\hline Clarias batrachus & - & + & - & + & - & - & - & - & - & + & 6 & 2 & 30 & $\mathrm{~N}$ & $\mathrm{C}$ \\
\hline Clarias gariepinus & - & - & - & - & - & - & + & + & - & + & 5 & 1.7 & 30 & A & $\mathrm{C}$ \\
\hline \multicolumn{16}{|l|}{ Family Poecillidae } \\
\hline Poecilia reticulata & - & - & + & + & + & + & + & + & + & - & 52 & 7.4 & 70 & A & N/A \\
\hline Xiphophorus hellerii & - & - & + & + & - & + & + & + & + & + & 37 & 5.3 & 70 & A & $\mathrm{O}$ \\
\hline \multicolumn{16}{|l|}{ Family Syngnathidae } \\
\hline Monopterus albus & - & - & - & + & - & - & - & + & + & - & 3 & 1 & 30 & $\mathrm{~N}$ & $\mathrm{C}$ \\
\hline \multicolumn{16}{|l|}{ Family Cichlidae } \\
\hline Oreochromis mossambicus & + & + & - & - & - & - & - & - & - & - & 6 & 3 & 20 & A & $\mathrm{C}$ \\
\hline Oreochromis niloticus & - & - & - & - & - & - & + & + & - & + & 9 & 3 & 30 & $\mathrm{~A}$ & $\mathrm{C}$ \\
\hline Oreochromis sp. & - & + & - & - & - & - & - & - & - & - & 1 & 1 & 10 & A & $\mathrm{C}$ \\
\hline Andinoacara pulcher & - & + & - & - & - & - & + & - & - & - & 9 & 4.5 & 20 & $\mathrm{~A}$ & $\mathrm{O}$ \\
\hline Andinoacara rivulatus & - & + & + & - & + & - & + & + & + & + & 17 & 2.4 & 70 & A & $\mathrm{O}$ \\
\hline Amphilophus citrinellus & - & - & - & - & - & - & - & - & - & + & 5 & 5 & 10 & A & $\mathrm{O}$ \\
\hline Cribroheros alfari & - & - & - & - & - & - & - & + & - & - & 1 & 1 & 10 & $\mathrm{~A}$ & $\mathrm{O}$ \\
\hline Cryptopheros spilurus & - & - & - & - & - & - & + & - & - & - & 2 & 2 & 10 & A & $\mathrm{O}$ \\
\hline Mayaheros uropthalmus & - & - & - & - & - & - & + & - & - & - & 4 & 4 & 10 & A & $\mathrm{O}$ \\
\hline Parachromis managuensis & - & - & - & - & - & - & - & - & - & + & 3 & 3 & 10 & A & $\mathrm{O}$ \\
\hline \multicolumn{16}{|l|}{ Family Anabantidae } \\
\hline Anabas testudineus & - & - & - & - & - & - & - & + & - & - & 1 & 1 & 10 & $\mathrm{~N}$ & $\mathrm{C}$ \\
\hline \multicolumn{16}{|l|}{ Family Belontiidae } \\
\hline Trichopodus trichopterus & - & - & - & - & - & - & + & + & - & + & 22 & 7.3 & 30 & $\mathrm{~N}$ & $\mathrm{O}$ \\
\hline \multicolumn{16}{|l|}{ Family Channidae } \\
\hline Channa gachua & + & - & + & - & + & - & + & + & + & + & 26 & 3.7 & 70 & $\mathrm{~N}$ & $\mathrm{O}$ \\
\hline Channa striata & - & - & - & - & - & - & + & + & - & - & 2 & 2 & 20 & $\mathrm{~N}$ & $\mathrm{C}$ \\
\hline Total species & 4 & 8 & 7 & 6 & 6 & 4 & 13 & 13 & 6 & 10 & & & & & \\
\hline
\end{tabular}

Note: Abund: abundance, Loc Dist: Local distribution, C: Consume fish, O: Ornamental fish, N: Native, A: Alien

The alien fish species distributed in freshwater in Mt. Galunggung areas, were recorded in 10 stations with the range from $10 \%$ to $70 \%$ of local distribution (Table 2). These species should be watched out by local people because they possibly alter their role to invasive species and impact the population of native fish species. For example, the red devil (Amphilophus labiatus) was first utilized as ornamental fish, but currently spread to many freshwaters of Indonesia and categorized as invasive species, such as in Sentani Lake (Ohee et al. 2018) and Sermo Reservoir in Kulon Progo, Yogyakarta (Ariasari et al. 2018). In this study, we did not find red devil, but we recorded its congener Amphilophus citrinellus. This species was known to occur in Sentani Lake like Oreochromis niloticus and Oreochromis mossambicus (Ohee et al. 2018).

\section{Description of alien fish species}

The alien species of freshwater fish in Mt. Galunggung areas comprised of 13 species. Description of each species provided here with scientific name, English name, morphological characters, geographic distribution, local distribution, threat, and utilization.

\section{Clarias gariepinus (Burchell, 1822)}

Synonym: Silurus gariepinus Burchell, 1822

English name: North African Catfish

Morphology character: Body shape elongated slim, with flat head and relatively small eyes. The snout is rounded and widened complemented by four pairs of barbels. Pectoral fin begins behind the gill cover to the bottom of the beginning of the dorsal fin. Separate elongated dorsal fin of the anal fin and tail fin, not having adipose fin. Bodycolor gray-green and those that resemble marble. The top or darker colored surface, while the bottom or belly more brightly colored.

Geography distribution: Africa, that is almost PanAfrica, absent from Maghreb, then the upper and lower Guinea and the Cape province and probably also Nogal 
province. While in Asia, including Jordan, Israel, Lebanon, Syria, and southern Turkey.

Local distribution: Sumatra, Java, Kalimantan

Threat: Its existence is suspected potential as a pest

Utilization: Consume fish

\section{Poecilia reticulata Peters, 1859}

Synonym: Acanthophacelus reticulatus (Peters, 1859)

English name: Guppy

Morphology character: These fish are smallish and slender for males, while females tend to be potbelly. Mouth is small and relatively facing upwards. Beginning dorsal fin is located in the central part of the body and opposite each other with the beginning of the anal fin. Guppy has very many color variations, and usually the male fish have color patterns more beautiful than females.

Geography distribution: South America; Venezuela, Barbados, Trinidad, northern Brazil, and the Guyanas

Local distribution: Sumatra, Java, Kalimantan, Lombok Threat: Its existence is suspected as potential pest

Utilization: Initially known for mosquito control

\section{Xiphophorus helleri Heckel, 1848}

\section{Synonym: Poecilia helleri (Heckel, 1848)}

English name: Green swordtail

Morphology character: Smallish body, slim and the male fish generally have lower lobe of the tail section extends like a sword. Mouth was small and relatively become pointed. Variations in the color pattern of fish are also very diverse, and in some species of black or red stripe runs across the middle of the body. Colored male fish more interesting than females.

Geography distribution: North and Central America: Rio Nantla, Veracruz in Mexico to northwestern Honduras. Africa: reported from Natal and eastern Transvaal in Lake Otjikoto, Namibia.

Local distribution: Sumatra, Java, Sulawesi

Threat: Its existence is suspected potential as a pest

Utilization: Initially known for ornamental fish

\section{Oreochromis mossambicus (Peters, 1852)}

Synonym: Chromis mossambicus Peters, 1852

English name: Mozambique tilapia

Morphology character: This fish flattened bodied large, and forehead with relatively large scales. The snout is relatively large, thick, can be brought forward and with strong jaws. Long dorsal fin and on the front resembles a hardened the front part of which have spines. Fish body color is black to gray. On the sides, there are 2-5 dark blotches sometimes faintly visible. During the spawning season, breeding male be colored black with white lower parts of head and red margins to dorsal and caudal fins.

Geography distribution: Africa; Lower Zambezi, Shiré and coastal from Zambezi delta to Algoa Bay. The Brak River in the Eastern Cape and in the Transvaal in the Limpopo system

Local distribution: Sumatra, Java, Sulawesi, Kalimantan

Threat: Its existence is suspected as potential pest Utilization: Consumption fish
Oreochromis niloticus (Linnaeus, 1758)

Synonym: Tilapia crassispina Arambourg, 1948

English name: Nile tilapia

Morphology character: This fish has a medium body, and the mouth is pointed upwards with a strong jaw. The color of the body is blackish or gray, with some dark transverse bands that will fade as an adult fish. Distinguishing feature is the existence of vertical stripes throughout depth of caudal fin, Generally numbering 7-12 stripes. In the spawning season, there is a reddish color on the tip of the dorsal fin, pectoral fin, abdominal fin and tail fin.

Geography distribution: Africa that in coastal rivers of Israel, Nile basin (including lake Albert, Edward, and Tana), Jebel Marra, Lake Kivu, Lake Tanganyika, Awash River, various Ethiopian lakes, Omo River system, Lake Turkana, Suguta River, and Lake Baringo. Furthermore in West Africa include the basins of The Senegal, Gambia, Volta, Niger, Benue, and Chad.

Local distribution: Sumatra, Java, Sulawesi, Kalimantan

Threat: Its existence is suspected as potential pest

Utilization: Consumption fish

\section{Oreochromis sp.}

Synonym: -

English name: -

Morphology character: Moderate body shape, large eyes, tip of mouth facing up. His whole body was white orange. In the operculum, there is dark coloration. The dorsal and anal fin is relatively pointed. Suspected to be the result of crossing between fellow tilapias.

Utilization: Consumption fish

\section{Andinoacara pulcher (Gill, 1858)}

Synonyms: Cychlasoma pulchrum Gill, 1858

English name: Blue acara

Morphology character: This fish is relatively large stature and somewhat compressed. The forehead tends to be somewhat or not noticeable. A characteristic that is around the mouth and cheek there is a line of vermiculite or curved blue. The body color is olive green, In the middle of the side of his body there is a black sphere, and equipped with eight obscure transverse bands. Male fish's body larger than the female and has a more varied color pattern.

Geography distribution: Central and South America that is Trinidad, Tobago, Colombia, and Venezuela.

Local distribution: Java

Threat: not harmful, but allegedly potential as a pest

Utilization: Ornamental fish

\section{Andinoacara rivulatus (Gunther, 1860)}

Synonym: Chromis rivulata Gunther, 1860

English name: Green terror

Morphology character: This big fish is rather flattened, and in the forehead is prominent. On the side of his body, there are regular black spots, and in the center of his body there is a black patch, but sometimes visible faint. The orange-yellow color is often seen clearly at the tips of the 
dorsal fin, caudal and pectoral fins. Male fish's body has a color pattern that is more beautiful than the females is green olive with white color, whereas females tend to be darker.

Geography distribution: South America that in Pacific slope from the Esmeraldas River in Ecuador to the Tumbes River in Peru

Local distribution: Java

Threat: not harmful, but allegedly potential as a pest Utilization: Ornamental fish

\section{Amphilophus citrinellus (Günther, 1864)}

Synonym: Cichlasoma citrinella (Günther, 1864)

English name: Midas cichlid

Morphology character: The body of this fish is large, and is thickly flattened. A wide mouth with a sturdy jaw. In general, most of the adult size of the fish has a bright orange to orange-red color. Adult males are larger in size with longer fins, and different humps on their heads. Some individuals have vertical lines on their sides and black spots on the base of the caudal fin.

Geography distribution: Central America is on the Atlantic slopes of Nicaragua and Costa Rica San Juan River drainage, including Lake Nicaragua, Managua, Masaya, and Apoyo.

Local distribution: Java

Threat: not harmful

Utilization: Ornamental fish

\section{Cribroheros alfari (Meek, 1907)}

Synonym: Cichlasoma alfari Meek, 1907

English name: Pastel cichlid

Morphology character: Body shape is not too big for cichlid size, and on the forehead is almost invisible there is a bump in the head. The tip of the muzzle is blunt with relatively thick lips. This fish is green with reddish fin tip, but there is also a bit yellowish color. The sides of the body are 5 to 6 dark vertical lines, and there is a black spot in the middle of the second and third vertical lines. In the fin decorated with gold dots, but often to the part around the head.

Geography distribution: Central America, namely on the Atlantic slopes starting from Honduras (Patuca River) to Costa Rica.

Local distribution: Java

Threat: not harmful

Utilization: Ornamental fish

\section{Cryptoheros spilurus (Günther, 1862)}

Synonym: Heros spilurus Günther, 1862

English name: Blue-eye cichlid

Morphology character: This fish has a medium body, and compressed. The top of the head from the tip of the mouth until the forehead slightly convex, without any prominent. Relatively small mouth with thick lips. The basic body color varies, including brown, blue, white, orange and gray. On the side of the body there is a dark vertical stripe of about 6 to 8 lines, and some species have black patches at the base of the caudal fin.

Geography distribution: Central America is on the Atlantic slopes starting from Belize to Nicaragua

Local distribution: Java

Threat: not harmful

Utilization: Ornamental fish

\section{Mayaheros urophthalmus (Günther, 1862)}

Sinonim: Heros urophthalmus Günther, 1862

English name: Mexican mojarra

Morphology character: $M$. uropthalmus has a relatively large body, and is thickly flattened. At the tip of the mouth until the forehead tends to be straight, and has no prominent. Generally, on the side of the body, there are 6 to 7 dark vertical lines, and will fade after the fish grows up. Male fish are larger than females, are more colorful and has extended dorsal and anal fins. This fish has a basic body color ranging from brown, red, to black, and will be more visible during the spawning season.

Geography distribution: Central America is in the Atlantic drainage from Mexico to Nicaragua

Local distribution: Java

Threat: not harmful

Utilization: Ornamental fish

\section{Parachromis managuensis (Günther, 1867)}

Synonym: Heros managuensis Günther, 1867

English name: Jaguar guapote

Morphology character: The mouth is large, the lower jaw is strong and slightly more prominent, complemented by enlarged canine teeth. In the eye, there is a black line that reaches the middle of the gill cover. Body fish color silvery or golden-green to purple, on the back of green moss with purple shades on the edge, and the belly is yellowish or whitish. The dorsal fin, anal and tail have black spots or spots, and sometimes are decorated with white, yellowish or bluish.

Geography distribution: Central America is on the Atlantic slopes starting from the Ulua River (Honduras) to the Matina River (Costa Rica).

Local distribution: Java

Threat: Potential pest

Utilization: Ornamental fish

Some problems of alien species, Dudgeon (2006) stated that as a factor to decrease the fish fauna diversity were habitat degradation and global warming. Commonly, the alien fish species have aggressive behavior, fast reproduction, disease carrier, and opportunity to freshwater habitat, and also estuarine (Blanchet et al. 2007; Paperno et al. 2008; Lusk et al. 2010; Kiruba-Sankar et al. 2018). In South Florida, alien fish species living in high levels of pesticide and mercury (Loftus et al. 2010). The morphological each alien species from Mt. Galunggung areas showed in Figure 3. 

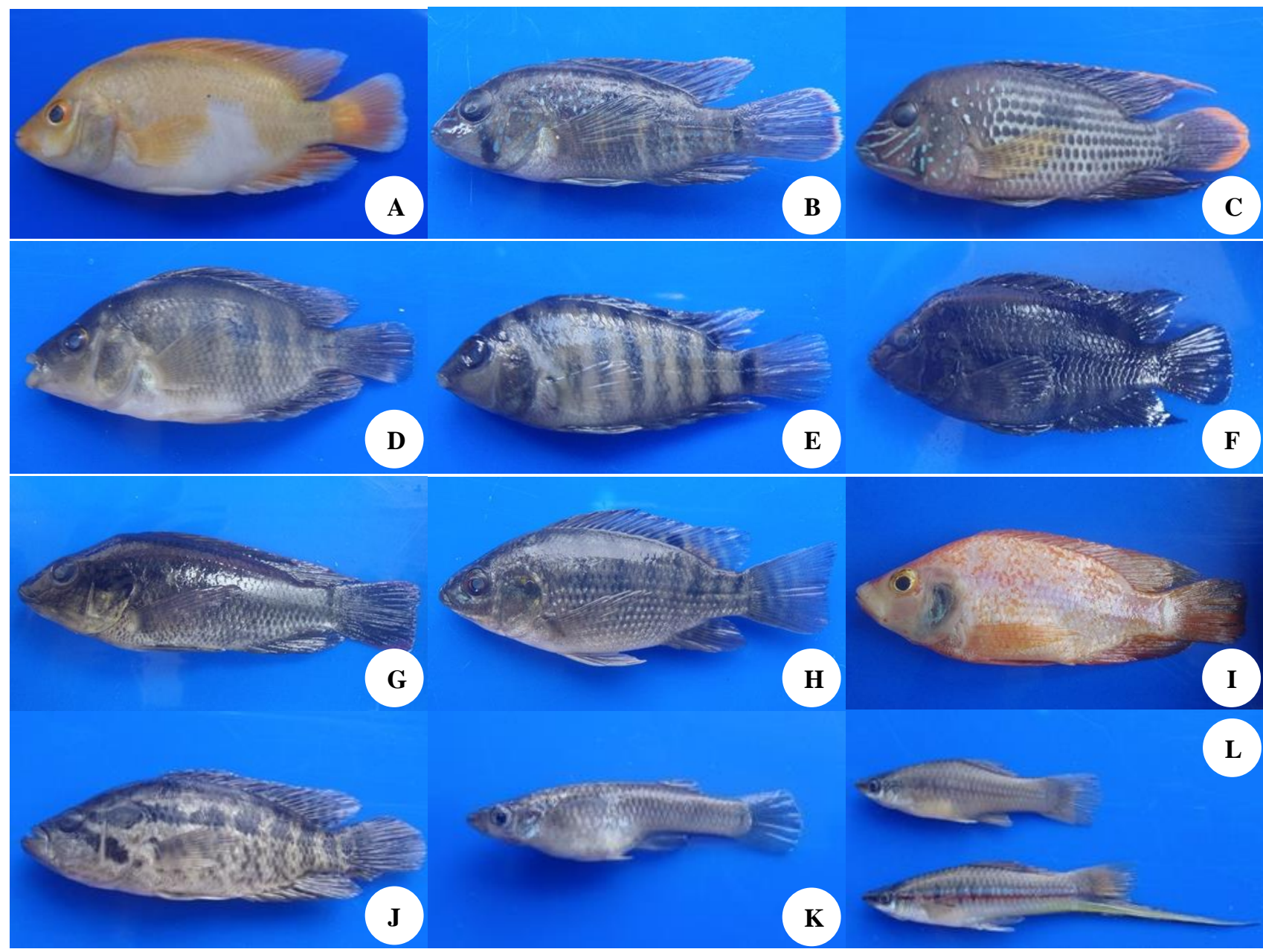

Figure 3. Alien fish species from Mt. Galunggung, West Java, Indonesia. A. Amphilophus citrinellus, B. Andinoacara pulcher, C. Andinoacara rivulatus, D. Cribroheros alfari, E. Cryptoheros spilurus, F. Mayaheros urophthalmus, G. Oreochromis mossambicus, H. Oreocrhromis niloticus, I. Oreocrhromis sp., J. Parachromis managuensis, K. Poecilia reticulata, L. Xiphophorus helleri (Photographs: Haryono)

In conclusion, Galunggung Mountain is inhabited by various species of fish, with spotted barb (Barbodes binotatus), bonylip barb (Osteochilus vittatus) and guppy (Poecilia reticulata) as the species which are evenly distributed at each observation station. The altitude is very influential on the number of fish species, as the diversity was higher in the Ciasem River, Cibukur River (lower parts 2) and the Citunggul River. The number of species introduced in the observation station tends to increase over time, so it will need close supervision to control the population that it will not grow in number nor widely spread.

\section{ACKNOWLEDGEMENTS}

We would like to express our gratitude to the Research Center for Biology-LIPI for providing a sponsor for this study. The field coordinator by Heryanto and Awal Riyanto, and all members of the team of Mt. Galunggung
Project are also acknowledged. Authors thanks also to Dr. Conni M. Sidabalok for prereview this article.

\section{REFERENCES}

Axelrods N, Burgess WE, Emmens CW. 1995. Mini Atlas of Freshwater Fishes, Mini editions. T.F.H. Publications, Inc., Boston.

Ariasari A, Helmiati S, Setyobudi E. 2018. Food preference of red devil (Amphilophus labiatus) in the Sermo Reservoir, Kulon Progo Regency. IOP Conferences Series: Earth Environ Sci 139 (2018) 012018. DOI: $10.1088 / 1755-1315 / 139 / 1 / 012018$.

Aryani N, Mardiah A, Azrita A and Syandri H. 2017. Influence of Different Stocking Densities on Growth, Feed Efficiency and Carcass Composition of Bonylip Barb (Osteochilus vittatus Cyprinidae) Fingerlings. Pakistan Journal of Biological Sciences, 20 (10): 489497. DOI: $10.3923 /$ pjbs.2017.489.497.

Azmir AI, and Samat A. 2010. Diversity and Distribution of Stream Fishes of Pulau Langkawi, Malaysia. Sains Malaysiana, 39 (6): 869875.

Batubara AS, Nur FM, Zulfahmi I, Rizal S, Efizon D, Elvyra R, Muchlisin ZA. 2019. Population Dynamics of The Groe Fish Barbodes binotatus (Pisces: Cyprinidae) in The Nagan River, Aceh Province, Indonesia. IOP Conferences Series: Earth Environ Sci 348 (2019) 012038. DOI: $10.1088 / 1755-1315 / 348 / 1 / 012038$. 
Beamish FWH, Saadrit P and Tongnunui S. 2006. Habitat Characteristics of Cyprinidae in Small River in Central Thailand. Environmental Biology of Fishes, 76: 237-253.

Blanchet S, Loot G, Grenouillet G, and Brosse S. 2007. Competitive interactions between native and exotic salmonids: A combined field and laboratory demonstration. Ecology of Freshwater Fishes, 16: 133143.

De Hoog JCM, Mason PRD, van Bergen MJ. 2001. Sulfur and Chalcophile Elements in Subduction Zones: Contrains form a Laser Ablation ICP-MS Study of Melt Inclusions from Galunggung Volcano, Indonesia. Geochimica et Cosmochimica Acta, 65 (18): 3147-3164

Dickey JWE, Cuthbert RN, Rea M, Laverty C, Crane K, South J, Briski E, Chang X, Coughlan NE, MacIsaac HJ, Ricciardi A, Riddell GE, Xu M, Dick JTA. 2018. Assessing the relative potential ecological impacts and invasion risks of emerging and future invasive alien species. NeoBiota 40: 1-24

Dudgeon D, Arthington AH, Gessner MO, Kawataba Z, Knowler DJ, Leveque C, Naiman RJ, Richard AHP, Soto D, Stiassny MLJ, Sullivan CA. 2006. Freshwater biodiversity: Importance, threats, status, and conservation challenges. Biol Rev 81: 163-182.

Eschmeyer WN. 1998. Catalog of Fishes Vol. 1-3. California Academy of Sciences, San Fransisco.

Fadjarajani S, Hendriawan N, Asari R. 2019. Modeling of Ecotourism Development in Tasikmalaya District, West Java. Proceedings International Symposium on Social Sciences, Education, and Humanities (ISSEH 2018). DOI: 10.2991/isseh-18.2019.27.

Froese R, Pauly D. 2019. www.fishbase.org.

Harrison E. 2014. Analyzing Invasion Success of the Mayan Cichlid (Cichlasoma urophthalmus; Günther) in Southern Florida [Dissertation]. Florida International University, Miami, FL

Haryono. 2012. Fish resources and potency in freshwater of Gunung Slamet areas also its management. In: Maryanto I, Noerdjito M, Partomihardjo T (eds) The ecology of Gunung Slamet. LIPI Press, Jakarta. [Indonesian]

Haryono. 2017. The freshwater fish fauna of Sawal Mountain Region, West Java, Indonesia. Journal Berita Biologi 16 (2): 147-156. [Indonesian]

Haryono. 2018. Ichthyofauna from Telaga Bodas areas in Upstream Citanduy watershed Garut Regency, West Java. Proceeding Indonesian Limnology Society Meeting 2017: 248-255. [Indonesian]

Herawati T, Rohman A, Wahyudewantoro G. 2019. Jenis Ikan Air Tawar di Jawa Barat dan Status Perlindungannya. Unpad Press, Sumedang. [Indonesian]

Inger RF, Chin PK. 1962. The Freshwater Fishes of North Borneo Fieldiana Zool (45). Chicago Natural History Museum, Chicago.

Jakubcinova K, Simonovic P, Stevove B, Atlagi JC, Kovac V. 2018. What can morphology tell us about ecology of four invasive goby species? J Fish Biol 90 (5): 1999-2019.

Kiruba-Sankar R, Raj JP, Saravanan K, Kumar KL, Angel JRJ, Velmurugan Roy ASD. 2018. Invasive Species in Freshwater Ecosystems - Threats to Ecosystem Services. In: Sivaperuman C, Velmurugan A, Singh AK, Jaisankar I (eds) Biodiversity and Climate Change Adaptation in Tropical Islands. Academic Press, London.

Kottelat M, Whitten AJ, Kartikasari SN, Wirjoatmodjo S. 1993. Freshwater Fishes of Western Indonesia and Sulawesi. Periplus Editions Limited, Jakarta.

Kottelat M. 2013. The fishes of the inland waters of Southeast Asia: A catalogue and core bibliography of the fishes known to occur in freshwaters, mangroves, and estuaries. Raffles Bull Zool Suppl 27: 1 663

Leveque E, Oberdorff T, Paugy D, Stiassny MLJ, and Tedesco PA. 2008 Global diversity of fish (Pisces) in freshwater. Hydrobiologia, 595: $545-567$

Liem KF. 1973. Evolutionary strategies and morphological innovations: Cichlid pharyngeal jaws. Syst Zool 22 (4): 425-441.
Li R, Chen Q, Tonina D, Cai D. 2014. Effects of upstream reservoir regulation on the hydrological regime and fish habitats of the Lijiang River, China. Ecol Eng 76, 75-83.

Loftus WF, Kobza R, Cook MI and Slone D. 2010. Tolerance of nonindigenous cichlid fishes (Cichlasoma urophthalmus, Hemichromis letourneuxi) to low temperature: Laboratory and field experiments in South Florida. Biol Invasions 12: 2441-2457.

Lusk S, Luskova V, and Hanel L. 2010. “Allien Fish Species in the Czech Republic and Their Impact on The Native Fish Fauna:. Folia Zool. 59 (1): 57-72.

Meffe GK, Snelson FF. 1989. An Ecological Overview of Poeciliid Fishes. In: Meffe GK (ed) Ecology and Evolution of Livebearing Fishes (Poeciliidae). Prentice-Hall, Englewood Cliffs, NJ.

Minchin D, Cook EJ, Clark PF. 2013. Alien species in British brackish and marine waters. Aquat Invasions 8 (1): 3-19.

Misra R. 1968. Ecology Workbook. Oxford \& IB Publishing Co., New Delhi.

Mohsin AKM, Ambak MA. 1983. Freshwater Fishes of Peninsular Malaysia. Penerbit Universiti Pertanian Malaysia.

Montag LF, da Silva Freitas TM, de Olivera Raiol RD, da Silva MV. 2011. Length-Weight relationship and Reproduction of The Guppy Poecilia reticulata (Cyprinodontiformes: Poeciliidae) in Urban Drainage Channel in The Brazilian city of Belem. Biota Neotrop, 11 (3): 93-97.

Muchlisin ZA, Siti-Azizah MN. 2009. Diversity and distribution of freshwaters fish in Aceh waters, northern Sumatra, Indonesia. Intl J Zool Res 5 (2): 62-79. DOI: 10.3923/ijzr.2009.62.79

Muchlisin ZA, Akyun Q, Rizka S, Fadli N, Siti-Azizah MN. 2015. Ichthyofauna of Tripa peat swamp forest, Aceh Province, Indonesia. CheckList 11 (2): 1-9. DOI: 10.15560/11.2.1560

Ohee EL, Sujartai P, Suriani BR, Surbakti, Barclay H. 2018. Rapid expansion and biodiversity impacts of the red devil cichlid (Amphilophus labiatus, Günther 1864) in Lake Sentani, Papua, Indonesia. Biodiversitas 19 (6): 2096-2103.

Paperno R, Ruiz-Carus R, Krebs JM, McIvor CC. 2008. Range expansion of the Mayan cichlid, Cichlasoma urophthalmus (Pisces, Cichlidae), above 288N latitude in Florida. Fla Sci 71: 293-304.

Pathak AK, Sakkar UK, Singh SP. 2013. Spatial Gradients in freshwater fish diversity, abundance and current pattern in the Himalayan region of upper Ganges Basin, India. Biodiversitas, 15 (2)186-194.

Prasetyo LB. 2004. Land-use change, land degradation and solution strategy: Case study in Citanduy Watershed. http://psp3.ipb.ac.id/file/Perubahan\%20Penutupan\%20....pdf. Access 22 April 2014.

Roberts TR. 1989. The Freshwater Fishes of Western Borneo (Kalimantan Barat, Indonesia). Calif Acad Sci Mem 14. San Fransisco.

Roberts TR. 1993. The Freshwaters Fishes of Java, as observed by Kuhl and van Hasselt in 1820-23. Zool Verh 285 (1993): 1-94.

Roesma DI, Chonelia A, Mursid A, Kamsi M. 2016. Fish diversity of the Batang Toru River System, South Tapanuli, North Sumatra. Biodiversitas 7 (2): 634-641. DOI: 10.13057/biodiv/ d170235

Suryaningsih S, Sukmaningrum S, Simanjuntak SBI, Kusbiyanto. 2018. Diversity and Longitudinal distribution of Freshwater Fish in Klawing River, Central Java, Indonesia. Biodiversitas. 19 (1): 85-92. DOI. 10.13057/biodiv/d190114.

Weber M, de Beaufort LF. 1913. The Fishes of the Indo-Australian Archipelago. II. Malacoptergii, Myctophoidea, Ostariophysi: I. Siluroidea. E.J. Brill Ltd., Leiden.

Woodford DJ, Richardson DM, Mac Isaac HJ, Mandrak NE, van Wilgen BW, Wilson JRU, Weyl OLF. 2016. Confronting the wicked problem of managing biological invasions. NeoBiota 31: 63-86.

Yao W, Kumar V, Rutschmann P. 2014. Simulating dam effects on river deformation and rainbow trout (Oncorhynchus mykiss) population number. CRC Press, New York. 